\title{
Corporate Governance and Economic Performance: The Limit of Short Termism
}

Francesco Di Tommaso, ORCID: https://orcid.org/0000-0002-5027-4208

$\mathrm{PhD}$ in Economics and Finance, University of Rome La Sapienza, Rome, Italy

\section{Arturo Gulinelli}

Studio Asse, Iel Ets Legal and Economic Association, Rome, Italy

\begin{abstract}
This article includes exploring arguments and counterarguments in the context of conducting a scientific discussion on the impact of corporate governance on a company's financial and economic performance. The main purpose of this paper is to determine the nature of the impact of corporate governance policy on the activities of economic entities. The systematization of literary sources and approaches to problem solving has shown that there are two opposing points of view: firm value, efficiency), on the other hand, - a number of scientists are convinced that there is a positive influence of the functioning of the corporate governance system on the valuation of listed companies. The work emphasizes the decisive role of the board of directors of the company in the development and adoption of the strategic direction of development of the organization. The author points out in the study the need for coordinated interaction of the board of directors with the financial management of the company and the business owners in order to increase the efficiency and profitability of the business entity. It is stated that the key economic tools for achieving and implementing the strategic plans of the company can be the key performance indicators and accordingly developed measures to achieve such success. As a result, it is justified that corporate governance should not be seen as a set of rules and mechanisms aimed at managing and controlling companies, but rather as a process by which companies become sensitive to stakeholder rights. The spread of corporate culture, according to the author of a work aimed at protecting the common interest, is facilitated by the existence of good rules and effective authorities that control their observance.
\end{abstract}

Keywords: government policy, regulation.

\section{JEL Classification: G18.}

Cite as: Tommaso, F. D., Gulinelli, A. (2019). Corporate Governance and Economic Performance: The Limit of Short Termism. Financial Markets, Institutions and Risks, 3(4), 49-61. http://doi.org/ 10.21272/ fmir.3(4). 49-61.2019

(C) The Authors, 2019. This article is published with open access at Sumy State University.

\section{Introduction. Corporate Governance: What is it? What is its framework and mechanism?}

There is no single accepted definition of corporate governance. There are differences in the definition based on the country we are considering. The main objective of this document is the agenda for corporate governance reform, mainly from the point of view of Italy. However, the American case of Enron is also used to demonstrate the need to improve corporate governance mechanisms. Coming to a shared definition of corporate governance is not an easy task. Corporate governance as a stand-alone discipline is relatively new. It is believed that the topic can be treated in a narrow or broad way, depending on the point of view of the political decision-maker, professional, researcher or theorist. It seems that the existing definitions of corporate governance fall into a spectrum, with "narrow" points of view on one side and "wider" points of view more inclusive on the other. One approach to corporate governance that adopts a narrow view is one in which corporate governance is limited to the relationship between a company and its shareholders. This is the traditional financial paradigm, expressed in the "agency theory". On the other side of the spectrum, corporate governance can be seen as a network of relationships, not only between a company and its owners (shareholders) but also between a company and a wide range of other "interested parties": employees, customers, suppliers, bondholders, just to name a few. This opinion tends to be expressed in the "stakeholder theory". This is a more inclusive and broader way of dealing with the issue of corporate governance and what is gradually attracting greater attention, since the issues of corporate responsibility and social responsibility are brought to the forefront of politics and practice in Italy and Europe. In general, the definitions of corporate governance in the literature tend to share certain characteristics, one of which is the notion of responsibility. Indeed, the narrow definitions are oriented towards corporate responsibility towards shareholders. Some 
Financial Markets, Institutions and Risks, Volume 3, Issue 4, 2019

ISSN (online) - 2521-1242 ISSN (print) - 2521-1250

narrower definitions of shareholders in emerging market corporate governance definitions focus in particular on the ability of a country's legal system to protect the rights of minority shareholders. However, these definitions are applicable mainly to emerging countries in terms of corporate governance and are not those that occur in the legislation on corporate governance in Italy. Wider definitions of corporate governance emphasize a broader level of accounting capacity for shareholders and other stakeholders. It can be said that the definition of corporate governance, which includes the responsibility towards a larger group of people than just shareholders, was strongly supported by institutional investors. This demonstrates an interest within the financial community for a broader integrated approach to corporate governance. The broader definitions consider that companies are responsible to the whole society, future generations and the environment. For the purposes of this document we agree with the broad definition of corporate governance, based on our research and our views on corporate governance issues in the integrated system. We suggest that corporate governance is the system of checks and balances, both internal and external to companies, which guarantees that companies fulfill their responsibility towards all their stakeholders and act in a socially responsible manner in all areas of their activity commercial. Throughout this document, we try to demonstrate that the theoretical frameworks that suggest that companies should be responsible only to their shareholders are not necessarily incompatible with the theoretical frameworks that support responsibility towards all stakeholders. The reason behind this argument is that shareholders' interests can only be satisfied by taking into account the interests of stakeholders, as the companies that are responsible to all their stakeholders have more success and more prosperity in the long run. The best definition of corporate governance is therefore based on the perception that companies can maximize long-term value creation by discharging their responsibility to all their stakeholders and optimizing their governance system. This opinion is supported by the practical cases of emerging markets. In fact, the empirical research carried out provided substantial support for the idea that the financial performance of companies is positively correlated with stakeholder-oriented corporate governance. Substantial evidence has been found that suggests a growing perception among institutional investors that there is a corporate governance dividend and a dividend linked to the responsibility of the parties involved. In conclusion, the research shows that "good" corporate governance, as well as corporate social responsibility, is significantly linked to the good financial performance of companies.

\section{Corporate Governance in emerging countries}

Numerous different theoretical frameworks have evolved to explain and analyze corporate governance in emerging countries. Each of these frameworks deals with corporate governance in a slightly different way, using different terminology and visualizes corporate governance from a different perspective, deriving from a different legislation and legal culture.

For this reason, as anticipated, we have dealt in our paper with the "stakeholder theory", born from a more socially oriented perspective on corporate governance. Although there are marked differences between the various frameworks, as everyone tries to analyze the same problems but from different perspectives. Here we try to define some of the most commonly used theoretical frameworks in accounting and finance disciplines and to specify some of the points in common and the differences between these competing paradigms. Let's examine the agency's theory.

\section{Theory of agencies in developed countries}

The introduction of limited liability and the opening of company ownership to the public through share ownership had a significant impact on the way companies were controlled. The market system in Italy and Europe is organized in such a way that the owners, who are mainly the shareholders of listed companies, delegate the management of the company to the management of the company.

There is a "divorce" between ownership and control that led to the notorious "Agency Problem". We discuss the extent to which there was a dispersion of participation, which consequently led to a separation of ownership and control in Italy. It has been shown that a similar ownership and control structure had been operating in Italy since the Renaissance. The agency's problem defines the company's managers as "agents" and the shareholder as the "principal" (in their analysis there is a shareholder with respect to "managers").

In other words, the shareholder, who is the owner or "principal" of the company, delegates the daily decisions of the company to the directors, who are the "agents" of the shareholders. The problem that arises following this business ownership system is that agents do not necessarily make decisions in the best interest of the principal. One of the most important presuppositions of agency theory is the divergence between the objectives 
Financial Markets, Institutions and Risks, Volume 3, Issue 4, 2019 ISSN (online) - 2521-1242 ISSN (print) - 2521-1250

and the birth of the conflict between the principal and the agent. In finance theory, a basic assumption is that the main goal for companies is to maximize shareholder wealth. In practice this is not necessarily the case. It is likely that in some companies, managers prefer to pursue their personal goals, such as obtaining the maximum possible bonuses. Managers are likely to show a tendency to "selfishness." This can result in a tendency to focus on investments in projects and companies that offer short-term profits rather than maximizing long-term shareholder wealth through investments, projects more sustainable and lasting, so the industry and especially the financial one is known for the "short term." The short term has been defined as a tendency to shorten the time horizon applied to investment decisions or to increase the discount rate to above that appropriate to the opportunity cost of the firm's capital It is thought to characterize the countries that are generally classified as "outsider-dominated" where this means that the economy is dominated by large companies controlled directly by their managers, but also indirectly through the actions of third parties, such as institutional investors.

Furthermore, the short-term pressure on companies emerged from the institutional investment community, which was more interested in making quick profits from portfolio investments than the survival and long-term growth of their investee companies. They have been accused of "churning out" actions in order to achieve high returns on investments, regardless of the effects of their decisions on managers, who are consequently under pressure and have to focus on short-term performance.

In this economic corporate governance environment, executives are tempted to supplement their salaries with as many benefits as possible (such as holidays through the company, office equipment and the like, free share assignments etc), bringing back to a reduction in value for shareholders. Italy (and other countries with similar market systems) these policies lead to a divergence in objectives. This "agency problem" brings shareholders the need to control the management of the company.

An important question is therefore: "how can shareholders exercise control over the management of the company?"; certainly through the appointment of independent directors, choosing systems of governance that strengthen the control of legality and control of the accounts, adopting the decision to control the remuneration policies of managers by linking it to medium and long-term returns, and finally intervening in strategic decisions

\section{Another important and basic assumption of agency theory}

There are several ways in which the interests of shareholders and managers can be aligned, but some are expensive. Agency costs stem from attempts by the shareholder to "monitor" business management. Shareholder monitoring is expensive, as it involves the launch of activities such as the commitment of shareholders (costly in terms of resources and time-consuming). Incentive schemes and contracts are examples of monitoring techniques. The literature shows that solutions to agency problems imply the creation of a "nexus" of optimal contracts (both explicit and implicit) between the management and the shareholders of the company. These include remuneration contracts for the business management of $\mathrm{m} / 1$ period. These contracts aim to align the interests of management with those of the shareholder. Although agency costs arise from the definition of these contracts, the costs are also borne by the agents. Managers are eager to demonstrate to the shareholder that they are responsible and that they are following the goal of maximizing shareholder wealth with a view to sustainability. They can provide additional information on risk management in their annual reports, for example, which will add costs to the accounting process, but will make the management useful and transparent. They can spend additional resources in organizing meetings with primary shareholders. The costs associated with these initiatives are called bonding costs. The cost of the agency resulting from management problems is also linked to the principal's monitoring costs and any residual losses (see Hill and Jones, 1992). One of the main reasons why the decisions of the principal and the agent diverge is their different attitude towards risk. This is referred to as the "risk sharing" problem, as managers and shareholders prefer different lines of action because of their different attitudes towards returns.

Now let's briefly introduce direct ways in which shareholders can "monitor" business management and help resolve agency conflicts. First, as owners of the company, the shareholders have the right to influence the way in which the company is managed and can do so by voting for the best management of operating assets. Shareholder voting rights are an important part of its financial activity. An area of financial literature is devoted to investigations on the use of voting rights by shareholders, in particular institutional investors. Shareholders can influence the composition of the board of directors in their investee companies (the companies in which they invest) by voting for operational assets. There are also a number of other issues on which shareholders can vote by expressing an attitude of greater participation (so-called "shareholder activism"). Although the 
Financial Markets, Institutions and Risks, Volume 3, Issue 4, 2019

ISSN (online) - 2521-1242 ISSN (print) - 2521-1250

right to vote is considered part of a shareholder's financial assets, institutional investors do not necessarily consider it an advantage, but rather a burden and a conditioning. Some pension fund managers believe that a weak point in the current system of corporate governance is precisely in the desire to exercise the right to vote, as the responsibility for ownership rests with people who often do not want to exercise it. Ownership of the shares is done because they give a good return, the enhancement of the right to vote is almost a burden and a responsibility from which one flees (this often happens for small shareholders).

Linked to the voting rights of shareholders is the acquisition mechanism, which represents another means of controlling the management of the company; it is necessary to underline the importance of the stock market as a means to regulate corporate management through the acquisition mechanism.

If the shareholders are not satisfied with the management structure of a company, they can vote in favor of an acquisition. Clearly, the threat of acquisition is in itself a disciplinary force for managers, as it is unlikely that they will lose their jobs. The long-term contracts of the administrators represent one of the means by which these can get a bit of security (even if the long-term contracts are becoming less used and less popular as the corporate governance reform proceeds after the financial crisis).

There are two theoretical approaches to Corporate Governance: The Finance Model Theory and the Stakeholder Theory.

\section{Traditional economic theory: the finance model}

Based on the agency's traditional theory (Jensen, Meckling 1976), there should be a positive relationship between corporate governance and business performance. The foundation of this theory lies in the assumption that the adoption of particular models of corporate governance making the supervision of the business model more stable creates the conditions for better performance; how? Precisely through careful monitoring, governance would force top management to invest in projects with a positive net present value and to reduce waste, so that many of the benefits fall on external investors.

The theory also argues that those working in companies with government models that are not properly devised are more likely to adopt sub-optimal strategies, manipulating social communications to highlight overperformance, resist acquisitions; as a result, their economic returns would be lower than those of similar companies that have more extensive corporate governance models. (see. Core et all 2006). Instead, by adopting good governance practices, companies can reduce agency costs and improve their performance. For these reasons, based on the agency's theory, we should find a positive relationship between the companies' performance and a high rating attributable to the implemented corporate governance model.

Not only are these assumptions not verifiable and verifiable in empirical evidence, as many international studies have claimed, but the supposed positive effect of increasing performance for example by discouraging investments with a low Net Present Value is often obtained, as we will see later, using discount rates that are too high, which lead to determining negative or reduced net present values, discouraging investments.

It is appropriate that other studies confirm the existence of a positive link between CG models and company performance. Since there is no single address it is difficult to arrive at a clear and definitive position; it is evident that a CG system based on the implementation of practices that ensure a management attentive to the creation and preservation of value in the medium and long term and that strives to promote respect for the rights of all stakeholders, more than others systems, reduce risks and guarantee, if not the achievement of better short-term economic performance, certainly a preservation of the company's assets over time.

Among the most relevant drivers that a good Corporate Governance system can introduce in the decisionmaking practices of companies there is probably the attention of managers and shareholders to the preservation of the value of the company in the future.

In fact, in the pre-crisis years, many private companies showed clear strategic management limits especially in the choice of investments and dividend policies, both pushed and voted to respond to short-term logic.

The agency relationship and the information asymmetries, which represent the most significant problems in relations between shareholders and management, have led, in the last thirty years, above all large companies, to a strong expansion of investment contraction policies, especially those long term. Dividend distribution and share buybacks were often preferred for investments to push quarterly prices. 
Financial Markets, Institutions and Risks, Volume 3, Issue 4, 2019 ISSN (online) - 2521-1242 ISSN (print) - 2521-1250

Strategies of this type undermine, however, the flows directed to the economic investments of the future. Preferring the distribution of dividends instead of investments in research and development activities can make the company attractive to speculative investors but certainly not to the attention of institutional investors.

In this way, capital is collected, but a capital that is not stable and that will probably soon move towards more profitable returns.

Instead, companies depend on the income flows and the cash flows that they will achieve in the future and these depend on productive and innovative investments made in the present.

\section{Short termism}

In this sense, the analysis conducted by Andrew Haldane (chief economist of the Bank of England) who together with other scholars has analyzed the financial statements of 624 companies listed partly on the British FTSE index and partly on the S\&P index is interesting. The period covered by the study concerns the years from 1980 to 2009. The model used by Haldane allowed the identification of short-termism policies, used by the target companies, through the measurement of the applied discount rate, which generally turned out to be be much higher than the real one. A high discount rate reduces the net present value of future flows, making an investment less attractive and cost-effective (the investment cost exceeds the NPV and is therefore discarded).

The author continues by commenting on the studies made by other economists and concludes that in Great Britain as in the USA, the two countries that have highly developed financial markets, the lack of investments in research and development are very large and that, while in the nineties or so half of the first two hundred companies worldwide that invested in research and development were, in fact, US or British, in 2009 the share of Anglo-Saxon companies active in R\&D activities had fallen by over $18 \%$. The reduction in investments leads to a contraction in the ratio between capital and production, thus a reduction in production capacity, national production and aggregate demand, with obvious macroeconomic effects.

Short-term strategies risk not only undermining the solvency of companies in the long term but also economic growth and the competitiveness of the nation's economy.

Addressing the issue of corporate governance by taking the traditional theory based on the finance model as a basis, it opens the reflection to other contradictions in the economic sphere; the governance model, also thanks to the theory of value, in corporate practices seems to have to be extended and oriented almost exclusively to the protection of shareholders' interests and to the maximization of the profit to be distributed. But this finalistic destination would seem to incorporate a possible defect or rather an absence of specification. What profit are we talking about? Short-term or medium-long term? The distinction is not trivial.

If we take the operating economic result, we essentially measure ourselves with the profitability of the own capital, which is a concept of the end of the period and of the remuneration of the risk capital; and it is in this area that the principle of efficiency comes into play, which forces companies to achieve the best result with the least use of resources. Efficiency, especially in times of economic crisis, pushes companies to adopt organizational models that reason in terms of short term, focusing on saving and cutting costs. And instead, in particular in the current production contexts in which the company is confronted with the variability of demand, the real challenge is to focus not only on costs - giving the level of prices - but on the best mix of process and product that leads to the maximization of the company's capital value. Thus the point of view is changed, passing from the side of the remuneration of the equity to that of the invested capital - from the perspective of the net assets to that of the investments - and at the same time as the idea of efficiency we add that of effectiveness (achievement of objectives of mounth / 1 term).

And in fact the economic result of the period is not enough to ensure long-term profitability, because the profit and therefore the efficiency of the management, although necessary, is continually called into question by the changed operating conditions in which the company operates and by the variability of all the factors of production (of their prices), and not only of financial capital. Without investments in research and development and without investments in human capital, the stability of every business model would be compromised.

An entity is really competitive if its government is able to manage and increase the value of its resources and distinctive skills, preserving them over time.

An economic value that takes into account only the short-term profit undermines the existence of every economic organization. 
Financial Markets, Institutions and Risks, Volume 3, Issue 4, 2019

ISSN (online) - 2521-1242 ISSN (print) - 2521-1250

\section{The stakeholder Theory}

We need to rethink the role of governance in terms of corporate management, moving towards a model that takes into account the needs of each stakeholder.

The stakeholder teory can represent a valid alternative for a "healthy" management of corporations.

It assumes that the management is the owner of a multi-fiduciary and exclusive relationship, which does not only concern the shareholders, but is aimed at a broad audience of stakeholders: the stakeholders.

This theory considers it necessary that companies do not have as their only concern the goal of creating share value; they must also meet the expectations of various stakeholders.

Therefore, the corporate governance processes include, in addition to the internal actors (shareholders, human capital), also the external ones (communities and control institutions etc.).

How should government action be exercised?

- identify the stakeholders;

- assess its weight with respect to the future development of company management;

- adopt the appropriate strategy to create common interests;

- understand the way in which the relationships between companies and stakeholders can guide the change in the management of the company;

- evaluate which practices can be put in place to manage collaboration between the various stakeholders;

- manage feedback with respect to deviations between governance actions applied and the result achieved.

It often happens that a governance structure inspired by the stakeholder teory creates a new corporate management culture, in which the company produces wealth and distributes it to the various subjects that contribute to its development.

Company performance is conditioned by the system of rights and obligations that binds it to each stakeholder.

Companies that achieve satisfactory long-term performance are those that manage to create a system of rights and obligations that allows them, not only to attract stakeholders, but also to ensure a balance between contributions received and rewards paid.

The sound management of society therefore passes from listening to the various positions and acting in an attempt to protect the interests of a multiplicity of subjects.

A company policy that complies with these principles can:

- reduce the reputational risk deriving from violations of regulations or environmental damage;

- creates a climate of trust that increases motivation and a sense of belonging;

- mitigates conflict with external control and supervisory organizations (trade unions, external supervisory bodies).

There is an opinion now widely shared on the fact that the company must answer for its choices and participate in the management of the problems of the community as a "social institution" that draws from the community the resources it needs to carry out the activity and that, through its actions, produces effects of various kinds (not always positive) on the environment that surrounds it.

Company economists refer to the concept of socialization of production costs, when the company transfers part of the costs to the community, which must be sustained in the course of production.

Moreover, there is a sort of implicit contract between the company and the company, from which derive a series of obligations of the first towards the second.

The company, as belonging to a community, assumes rights and duties towards the community in which it operates, both "local" and "global".

According to this socio-economic vision, as anticipated, the company therefore plays a social role, and therefore the content of corporate responsibility extends to a significant extent also including non-economic purposes such as the reduction of environmental pollution, the improvement of working conditions etc.

The social function of the company is complementary to the economic function. 
Financial Markets, Institutions and Risks, Volume 3, Issue 4, 2019

ISSN (online) - 2521-1242 ISSN (print) - 2521-1250

The acceptance of the socio-economic vision, which now appears to be the prevailing one, implies a new concept of management of society: the assumption of social obligations is based on a renewed relationship between business and the socio-economic environment, in its various components. The company and its management must act being accountable to all stakeholders - both the "primary" and the "secondary" ones by assuming obligations that go beyond the fair distribution of the economic value produced among all the subjects participating in its generation (workers, suppliers, customers, etc.): it must contribute to the "creation of the" extended value ", or the overall value for the stakeholders", which takes the form of increasing social well-being, improving the quality of life and in protecting the natural environment.

Even the strenuous defenders of the agency's theory, which wants the company managed to the direct and exclusive advantage of the shareholders, recognize the need for it to prove itself "sensitive" to that complex of unwritten laws, which are the fruit of the culture developed in the environment in which it operates. In the absence of this sensitivity, the company would risk losing that consent and that social legitimacy, which are indispensable for its survival and development.

Here, then, that an enlarged CG, which involves the involvement and listening to the positions of all stakeholders, becomes a fundamental tool in the current socio-economic context, which, if well addressed, can increase the value and sustainability of the business in the long term, increasing and improving corporate reputation.

Proper management of microeconomics (and therefore of businesses) is a vehicle for reducing the risk of systemic crises. In the last economic crisis, CG models too often did not prevent negative behavior contrary to the legitimate expectations of markets, customers, consumers and institutions in general.

In this perspective, micro and macroeconomics merge into a single social vision.

\section{The profitability of companies that claim to be socially responsible}

Organizations that evaluate the social, environmental and economic impact of businesses have multiplied for years.

An observatory at European level for example is that of Eurosif (www.eurosif.org). In 2018, this organization carried out a study that reveals how, in general, in recent years there has been a growth in the implementation of the strategy lines linked to the sustainability of the business of companies. In the financial sphere, large EU funds and not only are better orienting their investment portfolios towards ESG sustainability (an increase of around $60 \%$ with values managed close to 4 trillion).

The voting strategies exercised by asset managers in company assemblies assume an absolute importance in influencing the adoption of sustainability policies.

The reasons that tend to exclude companies from portfolio management are often anchored to sector logics (exclusion of companies that deal with arms, tobacco, fossil fuels, etc., where the tobacco industry is the most common exclusion criterion). The most common sectors also move, such as the involvement of businesses that operate in the retail trade with growth since 2014 that concerned only $3.4 \%$ of the activities, with significant value reached in 2018 with an interest recorded by $30 \%$ of the companies.

The EU legislator has understood the importance of the Corporate Governance models that ensure sustainability and we will see the EU SRDII Directive below.

\section{The importance of the Legislative Decree of 10 May 2019 n.49.}

Perhaps we should go back to the origin and as a note sir. Adrian Cadbury (see the Cadbury Code of the 1990s) brought back the sense of governance that at the time of Caucher Geoffrey meant sensibility and responsibility.

In this logic, the CG should not be seen as the set of rules and mechanisms that govern the management and control of companies but, rather, as the process by which companies are made sensitive to the rights of stakeholders.

As always, the issue is cultural, and the spread of a corporate culture aimed at protecting general interests is favored by the existence of good rules and by the presence of efficient authorities that monitor their compliance.

As we know on 10 June 2019, Legislative Decree 10 May 2019, n. 49 (the "Decree"), which implemented Directive (EU) 2017/828 (Shareholder Rights Directive II, "SHRD II"), amending directive 2007/36 / EC on 
Financial Markets, Institutions and Risks, Volume 3, Issue 4, 2019

ISSN (online) - 2521-1242 ISSN (print) - 2521-1250

the encouragement of long-term commitment of shareholders. It is true that the Decree came into force, except for the deferred application of some provisions, the same 10 June 2019. It should also be noted that the Decree provides, with certain exceptions, that the implementing provisions of the Decree are implemented within 180 days after its entry into force. The implementing provisions issued pursuant to the provisions replaced as we know will be repealed from the date of entry into force of the new provisions in the corresponding matters. Until that date, they continue to be applied without interruption.

Therefore, it should immediately be emphasized that the sanctions provided for ex novo by the Decree on the subject of related transactions in relation to the remuneration policy and the compensation paid, described below, would appear to apply only upon completion of the regulatory framework and therefore starting from adoption of regulatory provisions and vice versa.

We can summarize that the main changes introduced by the Decree to the Civil Code and Legislative Decree 58/1998 ("TUF") concern the following profiles.

\section{Transactions with related parties}

The Decree in fact amends the art. 2391-bis cod. civ. on the subject of related parties, now explicitly providing that CONSOB identifies:

a) the significance thresholds of transactions with related parties taking into account quantitative indices linked to the value of the transaction or its impact on one or more company size parameters. CONSOB can also identify criteria of relevance that take into account the nature of the transaction and the type of related party;

b) procedural and transparency rules proportionate to the relevance and characteristics of the transactions, to the size of the company or to the type of company that makes use of the risk capital market, as well as the cases of exemption from the application, in whole or in part, of the aforementioned rules;

c) the cases in which the directors, without prejudice to the provisions of Article 2391, and the shareholders involved in the transaction are required to abstain from voting on the same or safeguard measures to protect the interests of the company that allow the aforementioned shareholders of take part in the vote on the transaction.

It is a matter, in hindsight, of profiles already substantially regulated in the Regulation concerning transactions with related parties, adopted by CONSOB with Resolution no. 17221 of 12.3.2010, as updated with the changes made by resolution no. 19974 of 27 April 2017 (the "Consob OPC Regulation"). In any case, any actual change in the regulations relating to transactions with related parties currently in force must pass through a modification of the Consob OPC Regulation, expected, as mentioned, within 180 days of its entry into force.

The main novelty regarding related parties regards, for the moment, the sanctioning profiles: the new art. 192quinquies TUF introduced by the Decree, in fact, provides a specific administrative sanction for violation of the regulations in question. In particular, on one side there is a pecuniary administrative sanction from ten thousand euros to one hundred and fifty thousand euros towards the issuer.

On the other hand, unless the fact constitutes an offense, a pecuniary administrative sanction is envisaged ranging from five thousand to one hundred and fifty thousand euros against the persons who perform administrative and managerial functions, provided that their conduct has significantly affected the overall organization or on company risk profiles or has produced a serious prejudice for the protection of investors or for the transparency, integrity and proper functioning of the market (parameters introduced for the reference to Article 190-bis, paragraph 1, lett. ), TUF).

Identification of shareholders.

The Decree amends the art. 83-duodecies of the TUF on the subject of identifying shareholders, on the one hand limiting the right of issuers to identify shareholders to those who hold shares in excess of the $0.5 \%$ threshold of the share capital with voting rights, on the other on the other hand by eliminating the possibility for shareholders not to be identified. Moreover, this right can now be exercised by issuers regardless of the provision in the articles of association (the statutory provision remains instead for companies admitted to trading on multilateral trading systems).

In conclusion, the Decree also maintains the obligation for the issuer to initiate the identification process at the request of the shareholders representing at least half of the minimum shareholding established for the 
presentation of the lists of candidates for directors, as well as the obligation - in any case - information to the market in relation to the start of the identification process.

The new rules on the identification of shareholders will come into effect as of, and the implementation provisions will be adopted by the date of application of the Implementing Regulation (EU) 2018/1212 of 3 September 2018: therefore, from 3 September 2020.

\section{Report on the Crporate Governance remuneration policy and remuneration paid.}

Summarizing the Decree, in modifying the art. 123 -ter of the TUF, in particular:

- changes the formal name of the "remuneration report" in "report on the remuneration policy and the remuneration paid";

- specifies that the first section of this report must illustrate the remuneration policy "in a clear and understandable way";

- extends the obligation to describe the remuneration policy also with reference to the members of the supervisory bodies (without prejudice to the provisions of Article 2402 of the Italian Civil Code);

- specifies that the remuneration policy "contributes to the corporate strategy, the pursuit of long-term interests and the sustainability of the company and illustrates the way in which it provides this contribution";

- introduces the binding vote (instead of the advisory vote) of the meeting on the remuneration policy referred to in the first section of the report, also providing that the policy is subject to the vote of the meeting at least every three years (instead of on an annual basis). The vote of the shareholders is also expressly provided for in the event of policy changes;

- introduces the consultative vote on the second section of the report (on the fees paid);

The Decree also introduces the obligation for the legal auditing company to verify the preparation of the second section of the report.

We can conclude that the provisions apply to the reports on the remuneration policy and on the compensation paid to be published at the shareholders' meetings for the approval of the financial statements relating to financial years starting from 1 January 2019. It should also be noted that no option provided by the SHRD II for SMEs, to allow these companies to submit the section of the report on the compensation paid for the discussion at the meeting instead of the vote. The violation of the discipline of the remuneration report is for the first time assisted by a sanctioning apparatus. The Decree introduces, in fact, to listed companies for the violation of the provisions of art. 123-ter of the Consolidated Law on Finance and the related implementing provisions, as well as towards the persons who perform administrative, management or control functions, if their conduct has contributed to the violation of the aforementioned provisions by the company, the application of the pecuniary administrative sanction from ten thousand euros to one hundred and fifty thousand euros or the non-pecuniary administrative sanctions provided for by paragraph 1 of article 192-bis, TUF. Furthermore, it introduces the pecuniary administrative sanction from ten thousand euros to one hundred thousand euros for the auditor who fails to verify the preparation of the second section of the remuneration report.

\section{Last analysis: The right to ask questions before the Administrative meeting.}

Then the Decree maintains the current approach of the TUF - which provides for two different terms for the right to ask questions before the meeting -, however, increasing the terms available to issuers: the presentation of applications by shareholders can, in fact, now take place: (i) up to five trading days before the meeting - and in this case the company provides a reply at the latest during the meeting -; or

(ii) up to the record date (and therefore seven market days before the meeting), if the convocation notice provides for the company to provide, before the meeting, a response to the questions received. In the latter case the answers are always provided at least two days before the meeting, even through publication in a specific section of the company's website, but ownership of the right to vote can be attested even after the dispatch of the questions, provided that they are received by the third day following the record date.

The provision will apply to shareholders' meetings whose convocation notice is published after 1 January 2020 defining that:

Transparency of institutional investors, asset managers and voting consultants. 
Financial Markets, Institutions and Risks, Volume 3, Issue 4, 2019

ISSN (online) - 2521-1242 ISSN (print) - 2521-1250

The Decree introduces in the CFA, in Chapter II of Title III of Part IV, section I-ter (articles from 124-quater to 124-novies) on the transparency of institutional investors, asset managers and voting consultants, whose definitions are contained in art. 124-quater, of the TUF.

On the basis of the new provisions, the following is concluded:

- institutional investors and asset managers are required to adopt and communicate annually, based on the comply or explain principle, the commitment policy that describes the methods with which they monitor investee companies and communicate with them;

- the voting consultants must publish annually a report whose minimal content includes the scope and nature of the dialogue, if necessary entertained with the companies' object of their research and recommendations, the possible adhesion to a code of conduct or the reasons for not adhering. On these subjects, CONSOB can exercise the powers provided for by the articles 114 paragraphs 5 and 6 TUF (power to request information and documents necessary for information to the public) as well as 115 paragraph 1, lett. a), b), and c) (power to request the communication of news and documents, to take information, to carry out inspections).

The new provisions regarding institutional investors, asset managers and voting consultants, apply one year after the entry into force of the Decree, and therefore from 10 June 2020.

\section{Conclusion}

Perhaps we should go back to the origin and as a note sir. Adrian Cadbury (see the Cadbury Code of the 1990s) brought back the sense of governance that at the time of Caucher Geoffrey meant sensibility and responsibility.

In this logic, the Corpoate Governance should not be seen as the set of rules and mechanisms that govern the management and control of companies but, rather, as the process by which companies are made sensitive to the rights of stakeholders.

As always, the issue is cultural and the spread of a corporate culture aimed at protecting general interests is favored by the existence of good rules and by the presence of efficient authorities that monitor their compliance.

The future corporate governance will certainly be based on the management models of companies that are able to ensure the following aspects:

1. Business sustainability in the medium to long term

2. An attractive business climate

3. Respect for the rights of workers, the environment and local communities

4. Corporate reputation

5. The stability of profits instead of high profits in the short term.

\section{References}

1. Special report: corporate governance, investors fight back'. (2004, May17) Business Week. https://www.sec.gov/Archives/edgar/data/1018724/000119312516530747/d78603ddef14a.htm.

2. IPSOA, Amministrazione e Finanza (2019). 10, 5(4), 29-32. https://doi.org/10.22495/jgr_v5_i4_p4

3. Cabury, A. (Cadbury Code). Private communication. Business in the Community.

4. Republica Italiana, D. (2019, August 9). Legislative Decree of 10 May 2019 n.49.

5. Cadbury Committee (1992). Report of the Committee on the Financial Aspects of Corporate Governance. Retrived from: http://www.ecgi.org/ istepicodes/documents/cadbury.pdf

6. Collins, J., \& Porras, J. (1994). Built to last. New York: Harper Business. is sepepiRetrived from: https://www.amazon.com/Built-Last-Successful-Visionary- istepes:Essentials/dp/0060516402

7. Conference Board (2003). Commission on public trust and private enterprise: is recommendations. Retrived from: https://www.conference- board.org/pdf_free/SR-03-04-ES.pdf 
8. isteplDoyle, J. L., Colley, J., Stettinius, W., \& Logan, G. (2005). What Is Corporate Governance? New York: McGraw-Hill

9. El Nashar, T. (2016). The probable effect of integrated reporting on audit quality. Journal of Governance and Regulation, 5(2), 50-58. http://doi.org/ 10.22495/jgr_v5_i2_p6

10. Eun, C. S., Resnick, B. G., \& Sabherwal, S. (2004). International Finance. Wall Street Journal. April 9, 1996. https://link.springer.com/content/pdf/bbm\%3A978-3-030-02792-6\%2F1.pdf.

11. Ferri Di Fabrizio, L. (2017). The pattern of fraudulent accounting: Ethics, external auditing and internal whistle-blowing process. Journal of Governance and Regulation, 6(1), 12-25. http://doi.org/10.22495/jgr_v6_i1_p2

12. Feten, A., \& Salma, D.-A. (2015). The use of international standards in ethics education in the Tunisian audit context. Journal of Governance and Regulation, 4(4-4), 499-506. http://doi.org/10.22495/jgr_v4_i4_c4_p7

13. Gimbel, F. (2004, April 19). US activist launches hedge fund (for corporate governance). FT Fund Management. http://nylawyer.nylj.com/adgifs/decisions/120607hedgefund1.pdf

14. Gompers, P., Ishii, J., \& Metrick, A. (2001). Corporate governance and equity prices (NBER Working Paper No. 8449).

15. Habbash, M. (2012). Earnings management, audit committee effectiveness and the role of blockholders ownership: Evidence from UK large firms. Journal of Governance and Regulation, 1(4-1), 100116. http://doi.org/ 10.22495/jgr_v1_i4_c1_p1

16. ICGN (2002). Cross border proxy voting, case studies from the 2002 proxy voting season. London: International Corporate Governance Network.

17. IF AC (2003). Rebuilding public confidence in financial reporting: An international perspective. New York: International Federation of Accountants.

18. IFAC (2004). Enterprise governance: Getting the balance right. New York: International Federation of Accountants.

19. Kandemir, H. K. (2016). Auditing versus consultancy: a critique of the EU law reforms on the new form of auditing. Journal of Governance and Regulation, 5(3), 90-97. http://doi.org/10.22495/jgr_v5_i3_p8

20. Krauß, P., \& Zülch, H. (2013). The relation of auditor tenure to audit quality: Empirical evidence from the German audit market. Journal of Governance and Regulation, 2(3), 27-43. http://doi.org/10.22495/jgr_v2_i3_p2

21. Larcker, D., Richardson, S., \& Tuna, I. (2005, May 2). Ratings add fire to the governance debate. FT Mastering Corporate Governance. https://aaapubs.org/doi/pdf/10.2308/accr.2007.82.4.963

22. Ledimo, O., \& Martins, N. (2014). An audit of employee commitment to enable leaders to manage organizational talent. Journal of Governance and Regulation, 3(3-1), 128-133. http://doi.org/10.22495/jgr_v3_i3_c1_p6

23. Los Angeles Times (2004, April 3). Ex-exec tells of Adelphia fraud'. https://www.jstor.org/stable/29789727?seq=1\#page_scan_tab_contents

24. McKinsey \& Company (2002). Global investor opinion survey on corporate governance, London, McKinsey \& Company.Standard \& Poor's Governance Services (2002). Corporate Governance Scores: Criteria, Methodology and Definitions, New York, Standard and Poor's. https://www. mckinsey.com/ client_ service/corporate_finance/latest_thinking/mckinsey_on_finance/ /media/DD152F22B7CC4B099913E114A C5558FB.ashx

25. Monks, R. A. G., \& Minow, N. (2015). Corporate Governance (5thed.). Chichester, The UK: John Wiley \& Sons Ltd. http://doi.org/10.1002/ 9781119207238

26. Murase, H., Numata, S., \& Takeda, F. (2013). [Conference issue]. Journal of Governance and Regulation, 2(3), 7-23. http://doi.org/10.22495/jgr_v2_i3_p1 
Financial Markets, Institutions and Risks, Volume 3, Issue 4, 2019

ISSN (online) - 2521-1242 ISSN (print) - 2521-1250

27. Tayan, B. \& Larcker, D. F. (2015). Corporate governance matters: A closer look at organizational choices (2nd ed.). New Jersey: Pearson Education. Retrieved from: https://www.amazon.com/CorporateGovernance-Matters- Organizational-Consequences/dp/0134031563

28. Tricker, P. I. (2017). Corporate governance: principles, policies, and practices. Oxford, the UK: Oxford University Press. Retrieved from: https://global.oup.com/ukhe/product/corporate-governance9780198702757? cc=ua\&lang=en\&

29. UNCTAD (2003). Case study on corporate governance disclosures in the United States of America (Report No. TD/B/Com.2/ISAR/19/). Retrieved from: https://unctad.org/en/docs/c2isar19_en.pdf

30. UNCTAD (2005). 2005 Review of the implementation status of corporate governance disclosures (Report No. TD/B/COM.2/ISAR/CRP.1).

31. Velte, P. \& Stiglbauer, M. (2012). Impact of auditor and audit firm rotation on accounting and audit quality: A critical analysis of the EC regulation draft. Journal of Governance and Regulation, 1(3), 7-13. http://doi.org/ 10.22495/jgr_v1_i3_p1

32. Velte, P., \& Eulerich, M. (2014). Increased auditor independence by external rotation and separating audit and non-audit duties? - A note on the European audit regulation. Journal of Governance and Regulation, 3(2), 53-62. http://doi.org/10.22495/jgr_v3_i2_p5

33. Webley, S., \& More, E. (2003). Does business ethics pay: Ethics and financial performance. London: Institute of Business Ethics. Retrieved from: https://www.ibe.org.uk/userfiles/doesbusethicpaysumm.pdf

34. Wilkinson, N., \& Coetzee, P. (2015). Internal audit assurance or consulting services rendered on governance: How does one decide? Journal of Governance and Regulation, 4(1-2), 186-200. http://doi.org/10.22495/jgr_v4_i1_c2_p3

35. Relazione Assonime "La Corporate Governance in Italia: autodisciplina, remunerazioni e comply-orexplain (anno 2017) del Febbraio 2018; http://www.assonime.it/attivita-editoriale/studi/Pagine/note-e-studi-22018.aspx

36. 2017 CSR RepTrak - How to use data to connect CSR and Reputation and be relevant for the business; https://www.reputationinstitute.com/sites/default/files/pdfs/2017-Italy-CSR-RepTrak.pdf

37. Report on corporate governance of Italian listed companies 2017 - fonte Consob; http://www.consob.it/web/consob-and-its-activities/rcg2017

38. ZAMAGNI S., «Responsabilità sociale delle imprese e "Democratic Stakeholding"», Forlì, Aiccon, WorkingPaper n. 28, 2006; http://www.consob.it/web/consob-and-its-activities/rcg2017

39. Milton Friedman - "The Social Responsibility of Business is to Increase its Profits" New York Times Magazine 1970; https://www.duo.uio.no/bitstream/handle/10852/38408/ Mertens_Filsosofi_Master. pdf? sequence $=$

40. Tarantola A., 2011, Il ruolo del risk management per un efficace presidio dei rischi: le lezioni della crisi, Intervento alla CommunityCib - SDA Bocconi, Milano, 10 novembre; http://umich.edu/ $\sim$ thecore/doc/Friedman.pdf

41. Amartya K. Sen Etica ed Economia Editori Laterza 1988; https://archiviomarini.sp.unipi.it//541/1/Amartya\%20Sen,\%20la\%20filosofia\%20politica\%20(S_\%20Carus)

42. Andrew Haldane - The costs of short-termism BOE 2016; https://www.bis.org/review/r171013f.pdf

43. Il codice della crisi di impresa schema di Dlgs del 10/1/2019 https://www.altalex.com/ documents/news/2018/11/28/codice-crisi-impresa-e-insolvenza

44. Ahmad, M., \& Alshbiel, S. (2016). Women in Jordanian banks and performance: Financial accounting measurement.[Special issue]. Risk governance \& control: financial markets \& institutions, 6(3-1), 717. http://dx.doi.org/10.22495/rcgv6i3c1art1 
45. Puntillo, P. (2012). An empirical analysis of fiscal federalism implementation and of cost accounting in Italian public administrations. Risk Governance and Control: Financial Markets \& Institutions, 2(3), 6475. http://dx.doi.org/10.22495/rgcv2i3art5

46. Agriyanto, R., Rohman, A., Ratmono, D., \& Ghozali, I. (2016). Accrual based accounting implementation: An approach for modelling major decisions. Risk governance \& control: financial markets \& institutions, 6(4-special issue), 531-539. http://dx.doi.org/10.22495/rgcv6i4siart12

47. Rasyid, A., Sugiarto D., E., \& Kosasih, W. (2017). Management accounting techniques and corporate performance of manufacturing industries. Risk governance \& control: financial markets \& institutions, 7(2), 116-122. http://dx.doi.org/10.22495/rgcv7i2art11

48. Alrabba, H. M., \& Ahmad, M. A. (2017). The role of enterprise resource planning (ERP) system in advancing the country of Jordan towards international standard accounting practices and accounting mechanisms. Risk governance \& control: financial markets \& institutions, 7(2), 7694. http://dx.doi.org/10.22495/rgcv7i2art8

49. Baatwah, S. (2016). Audit tenure and financial reporting in Oman: Does rotation affect the quality? [Special issue]. Risk governance \& control: financial markets \& institutions, 6(3-1), 1829. http://dx.doi.org/10.22495/rcgv6i3c1 art2

50. Alhadab, M. (2016). Auditor report and earnings management: Evidence from FTSE 350 companies in the UK. Risk governance \& control: financial markets \& institutions, 6(4-2), 334344. http://dx.doi.org/10.22495/rgcv6i4c2art11

51. Kusumastuti, R., Ghozali, I., Fuad (2016). Auditor professional commitment and performance: An ethical issue role. Risk governance \& control: financial markets \& institutions, 6(4-special issue), 540548. http://dx.doi.org/10.22495/rgcv6i4siart13

52. Mynhardt, RH., Plastun, A., \& Makarenko, I. (2017). Competitiveness of the Ukrainian audit market. Risk governance \& control: financial markets \& institutions, 7(2-1), 177193. http://dx.doi.org/10.22495/rgcv7i2c1p6

53. Drogalas, G., \& Siopi, S. (2017). Risk management and internal audit: Evidence from Greece. Risk governance \& control: financial markets \& institutions, 7(3), 104-110. http://doi.org/10.22495/rgcv7i3p10

54. van der Nest, D.P., Smidt, L., \& Lubbe, D. (2017). The use of generalised audit software by internal audit functions in a developing country: A maturity level assessment. Risk Governance and Control: Financial Markets \& Institutions, 7(4-2), 189-202. http://doi.org/10.22495/rgc7i4c2art2

55. Lemonakis, C., Ballas, P., Balla, V., \& Garefalakis, A. (2018). Audit fees and pricing strategy: Do restatements of internal control reports and earnings matter? Risk Governance and Control: Financial Markets \& Institutions, 8(2), 63-73. http://doi.org/10.22495/rgcv8i2p4

56. El-Halaby, S., Hussainey, K., Marie, M., \& Mohsen, H. (2018). The determinants of financial, social and Sharia disclosure accountability for Islamic banks. Risk Governance and Control: Financial Markets \& Institutions, 8(3), 21-42. http://doi.org/10.22495/rgcv8i3p2

57. Eltweri, A., Altarawnah, M., Al-Hajaya K., \& Al-Karaki, W. (2018). Auditing profession regulation: Lesson learned from code and common law countries regulatory approaches. Risk Governance and Control: Financial Markets \& Institutions, 8(3), 80-101. http://doi.org/10.22495/rgcv8i3p6

58. Ferreira, J. V. (2018). The role of the external auditor in corporate governance: The case of companies listed in the NYSE Euronext Lisbon. Risk Governance and Control: Financial Markets \& Institutions, 8(4), 38-51. http://doi.org/10.22495/rgcv8i4p5

59. Tutino, M., \& Merlo, M. (2019). Accounting fraud: A literature review. Risk Governance and Control: Financial Markets \& Institutions, 9(1), 8-25. http://doi.org/10.22495/rgcv9i1p1 Amira, H., \& Nuha, B. Q. (2019). The impact of conditional conservatism on creative accounting: A suggested framework. Risk Governance and Control: Financial Markets \& Institutions, 9(1), 3344. http://doi.org/10.22495/rgcv9i1p3 